\title{
DE LA MITOLOGÍA CLÁSICA A LA LITERATURA CANARIA: EL MOTIVO DEL PARAÍSO
}

\author{
Luis Miguel Rodríguez Díaz \\ Universidad de Las Palmas de Gran Canaria \\ https://doi.org/10.18778/8220-195-6.03
}

\section{Resumen}

El autor fundacional de la literatura canaria, Cairasco de Figueroa (1538-1610), elabora un imaginario de las Islas que adapta a la realidad insular diferentes rasgos del motivo literario clásico del paraíso. Se analiza el papel de la teoría racionalista del mito y su método interpretativo en el proceso de creación de imágenes de Canarias a partir de dos espacios míticos grecolatinos (los Campos Elisios y las Islas de los Afortunados).

Palabras clave: Literatura canaria. Imaginario. Paraíso. Campos Elisios. Islas de los Afortunados.

En el año 1478, con la fundación de la ciudad de Las Palmas de Gran Canaria, arranca el proceso histórico que dará lugar al nacimiento de una nueva variedad dentro del ámbito de las literaturas hispánicas: la literatura canaria. Su eclosión resultará más o menos paralela en el tiempo a la de las literaturas del continente americano, descubierto y colonizado pocos años después y, debido a esta sincronización evolutiva, la emergente literatura insular compartirá con sus congéneres del otro lado del Océano algunos factores condicionantes que la hacen semejante a ellas en ciertos aspectos. El principal de ellos es que surge como producto de una nueva sociedad, de origen híbrido, en la que se mezclan gentes procedentes de distintos lugares de la Península Ibérica y Europa con habitantes autóctonos prehispánicos; y, en consecuencia, que será la expresión de una nueva cultura, resultante de ese mestizaje y de la adaptación a un medio natural diferente al del Viejo Continente. 
Un siglo después, en la segunda mitad del XVI, en esa ciudad del Atlántico se ha desarrollado ya la nueva sociedad isleña, que comienza a definir sus señas de identidad y a esbozar una personalidad propia. Al mismo tiempo, se va gestando su cosmovisión particular, lo que a su vez estimula la exploración de los cauces expresivos que permitan plasmarla. Los artistas emprenden así la difícil tarea de dar forma a un imaginario de lo canario, es decir, un conjunto de representaciones culturales con las que dar un sentido al Nuevo Mundo insular en el que les ha tocado desenvolverse, y que sean además suficientemente distintivas e identificables tanto para ojos propios como para extraños. De forma paralela a lo que acontece por entonces en las letras americanas, el motivo del paraíso va a ocupar en ese imaginario una posición central.

Tenemos la suerte de poder asistir a toda esta intensa actividad cultural gracias a la extensa producción literaria que se registra en las Islas por esas fechas. Tal efervescencia creativa se concentra precisamente en la ciudad de Las Palmas, en torno a la figura de Bartolomé Cairasco de Figueroa (1538-1610). Cairasco encarna a la perfección esa nueva sociedad mestiza y esa nueva cultura híbrida de que hablábamos antes, y es el autor de la obra poética (épica en su mayor parte) más importante en cantidad y calidad de su tiempo en las Islas. Desde 1580 mantiene en el jardín de su casa de Las Palmas de Gran Canaria una tertulia, consagrada a Apolo Délfico, en la que se reúne un círculo de escritores de distintos géneros. Las obras de todos ellos, tanto en verso como en prosa, gravitan en torno al tema común de Canarias, evidencian estrechas relaciones entre sí y, sobre todo, manifiestan un mismo imaginario común, que parece plenamente constituido ya, en sus elementos principales, tan solo un siglo después de la fundación de la ciudad que acoge su tertulia. Podemos deducir, pues, que la creación de dicho imaginario es una auténtica obra colectiva del grupo artístico nucleado en torno a Cairasco.

Como es natural, estos autores trabajaron siguiendo las corrientes culturales del momento que, en pleno Renacimiento, prescribían el recurso a los autores grecolatinos como modelo y fuente de inspiración. Encontraron así a su disposición una larga 
tradición clásica que identificaba ciertas islas del Atlántico con dos espacios míticos: las Islas de los Afortunados y los Campos Elisios (Martínez, 1992: 39-85). Ambos lugares tenían en común que estaban considerados los más importantes paraísos de la mitología clásica. El segundo gozaba de un especial prestigio por ser el más antiguo y el único que aparece en Homero ( $\mathrm{Od}$. IV, 565-568), que lo describe en estos brevísimos términos: "Allí la vida de las personas es más fácil: no existe la nieve ni el invierno largo, ni tampoco la lluvia, sino que el río Océano deja siempre paso a los soplos del viento Céfiro, que sopla sonoramente para refrescar a las personas".

Los rasgos de este paraíso homérico no pretendían ser los de un territorio o país concreto. El clima suave, la ausencia de frío y lluvia y la vida fácil de sus habitantes son características universales de todos los paraísos en todas las culturas del planeta: son intrínsecos al concepto (si no fueran así, no serían paraísos) y, por tanto, estereotipados. Su origen, como todos los mitos, está en el terreno de las creencias, no en la geografía. Pero la identificación entre espacio mítico y espacio real resultará posible gracias a una teoría filosófica sobre la naturaleza del mito muy antigua (aparece con los sofistas griegos, en el siglo $\mathrm{V}$ a.C.) y que es una de las grandes aportaciones del pensamiento griego a la cultura occidental: la teoría racionalista.

De acuerdo con la misma, los mitos tienen su origen en lugares, sucesos o personalidades reales del pasado que, por su especial rareza o importancia, se han ido trasmitiendo de generación en generación, y que con el paso del tiempo han sufrido paulatinamente un doble proceso: la pérdida de sus características naturales y racionales y la adquisición de rasgos sobrenaturales, irracionales y, en definitiva, fantásticos. En otras palabras, la teoría racionalista cree en la existencia del fenómeno de la mitificación, es decir, el paso de lo real a lo mitológico (García Gual, 2010: 171-183).

Consecuentemente, los racionalistas creen que el mito tiene dos planos: uno superficial, que es ficticio y fabuloso, y otro profundo, que contiene una realidad (Buffiere, 1973: 33-36). Según una famosa definición del siglo I d.C., "El mito es una historia falsa (lógos pseudés) que ilustra una verdad” (Teón, Progym. 3). Por tanto, el 
estudio del mito debe consistir, esencialmente, en recorrer el camino a la inversa, de lo mítico a lo real, averiguando cuál es esa realidad objetiva subyacente al mito, para así des-mitificarlo. Los mitos pueden y deben entonces ser traducidos, es decir, explicados mediante el lenguaje científico: basta con eliminar el ropaje externo propiamente mítico para alcanzar su significado oculto.

En el caso concreto de un espacio mítico como el paraíso, que es un concepto simbólico, situado siempre fuera de este mundo y, por tanto, inaccesible, se convierte gracias a esta teoría en un sitio real, de este mundo y, por ende, a nuestro alcance. La exégesis racionalista de su significado profundo se había realizado ya en la Antigüedad, como atestigua el escritor y filósofo Plutarco (siglo II d.C.), quien se basa precisamente en el famoso pasaje homérico de los Campos Elisios:

\begin{abstract}
Allí unos marineros con quienes habló le dieron noticias de ciertas islas del Atlántico, de las que venían entonces (...) y se llaman Islas de los Afortunados. Las lluvias en ellas son moderadas y raras, pero los vientos, suaves y provistos de rocío, hacen que aquella tierra blanda y rica no sólo se preste al arado y los cultivos, sino que también produzca espontáneamente frutos que por su abundancia y buen sabor bastan para alimentar sin trabajo y afán a un pueblo ocioso. Un aire sano, por el que las estaciones casi se confunden, sin que haya grandes cambios, es el que reina en aquellas islas, pues los vientos del norte y del este que soplan desde tierra recorriendo un largo trecho van decayendo y llegan sin fuerza; y los vientos del mar, el ábrego y el céfiro, siendo portadores de lluvias suaves y escasas, con su húmeda bonanza refrigeran y nutren las plantas. De manera que incluso aquellos bárbaros tienen la firme opinión de que allí estuvieron los Campos Elisios, aquel lugar de residencia de los bienaventurados que cantó Homero. (Vida de Sertorio, 8)
\end{abstract}

En resumen, Plutarco viene a decir que el paraíso grecolatino tuvo su origen en unos espacios reales (unas islas del Atlántico) que por sus características tan especiales (su clima y su extraordinaria fertilidad) fueron mitificados, es decir, adornados con 
rasgos fabulosos (como, por ejemplo, que allí residen las almas bienaventuradas), y paulatinamente trasformados en mito. Para demostrar su afirmación recurre a un dato, ya no fantástico y sobrenatural como en Homero, sino científicamente objetivo, basado en las observaciones empíricas de los marinos que las frecuentaban: en dichas islas del Atlántico existe un régimen continuo de vientos marítimos húmedos que causa una ausencia de cambios estacionales, una temperatura y humedad constantes, y una prodigiosa fertilidad. Al hilo de su argumentación, Plutarco nos está trasmitiendo así la primera descripción histórica del clima de las Islas Canarias y su principal y más distintivo fenómeno atmosférico: los vientos alisios. El autor, por un lado, desmitifica el mito, demostrando que bajo la ficción homérica subyace una realidad, extraordinaria, sí, pero auténtica; y por otro, también traduce el mito al lenguaje de la ciencia, revelándonos que Homero, al hablar de algo sobrenatural (un paraíso), se refiere en verdad a algo perfectamente natural (una región del planeta con un clima determinado). De esta forma, el discurso mitológico se transforma en discurso geográfico.

Sin embargo, a pesar de contar con la teoría y la metodología adecuadas, los filósofos griegos y romanos no pudieron llegar muy lejos en su reinterpretación del paraíso mítico a partir del archipiélago atlántico. Ello se debe a que esta teoría racionalista necesita operar, como hemos visto, con datos empíricos. Pero los datos acerca de Canarias que poseían los antiguos eran escasos y de mala calidad, por culpa de la falta de contactos directos con las Islas y el consiguiente desconocimiento. Por esa razón, su identificación de elementos reales en las descripciones míticas de las Islas de los Afortunados y los Campos Elisios permaneció en el nivel que vemos en Plutarco.

Sin embargo, más de un milenio después la situación cambiaría de forma drástica con el poblamiento de Canarias. Los habitantes isleños del siglo XVI tenían, como es lógico, un amplio y detallado conocimiento de su medio ambiente, y pronto se percataron de la gran cantidad de singularidades de todo tipo que su Naturaleza contenía. Con tal abundancia de características naturales especiales y extraordinarias, el método racionalista podía ahora convertirse en una herramienta mucho más poderosa, de 
un alcance insospechado. Resultó así que los miembros del cenáculo de Apolo Délfico se vieron bien surtidos de aquello que les había escaseado a los autores antiguos: los datos empíricos que faltaban para completar la exégesis del mito. Retomaron entonces el camino que Plutarco les había mostrado y, siguiendo sus mismas pautas, fueron capaces de desarrollar toda una estrategia de apropiación de la tradición clásica del paraíso.

Dicha estrategia consistió, lógicamente, en proseguir la identificación entre fenómenos naturales típicos y distintivos de las Islas Canarias, por un lado, y rasgos paradisíacos susceptibles de una interpretación racionalista, por otro. A continuación, el producto de dicha equiparación entre lo real y lo mitológico serviría de base para la creación de las diferentes representaciones que conforman el imaginario de la cosmovisión insular, que estaría así establecido a partir de la iconología de los Campos Elisios y las Islas de los Afortunados grecolatinos. Como resultado, las imágenes de Canarias son, en definitiva, imágenes del paraíso.

Señalábamos antes el papel central que juega la figura de Cairasco en todo este proceso de creación del imaginario, y es precisamente en su obra donde encontramos los ejemplos más claros de dicha estrategia. Si Plutarco había ya racionalizado el clima de los Campos Elisios homéricos, explicándolo como una mitificación del fenómeno de los alisios, el poeta canario amplía esa racionalización acudiendo a otros dos fenómenos meteorológicos especiales de las Islas (y producidos precisamente por los alisios): la isoterma anual de $18-20^{\circ} \mathrm{C}$ y la nubosidad estratiforme (el mar de nubes). Así, en una descripción de la isla de Gran Canaria dice:

Aquí los frescos aires, las mareas, el toldo de las nubes relevadas, de los floridos campos las libreas, los verdes bosques, aguas plateadas, el temple, sanidad, ricas preseas, los cantos de las aves variadas, en sagrado silencio, en paz entera conservan una eterna primavera.

(Sánchez, 1989: 178) 
Plutarco disponía ya en su época de una información bastante exacta acerca del clima real de las Islas: "las estaciones se confunden, sin que haya grandes cambios"; pero Cairasco disfrutaba, como es lógico, de un grado aún mayor de conocimiento al respecto, y sabía que, de hecho, existe una sola estación y con una temperatura media determinada; a partir de ese dato, más preciso, acuña una imagen que parece sobrenatural $y$, por tanto, resulta netamente mítica: una eterna primavera. A diferencia de Plutarco, Cairasco conocía otra especificidad de la meteorología insular que parece corresponderse con ciertas palabras de Homero: "que sopla sonoramente para refrescar a las personas"; la nubosidad producida por el alisio, en contante sucesión, es la principal causante de la ausencia de calores veraniegos, al generar una pantalla sombreadora contra el sol; con ese nuevo dato el poeta crea la imagen de otro milagro paradisíaco: la isla posee un "toldo de nubes relevadas".

Los textos clásicos sobre las Islas de los Afortunados y los Campos Elisios aludían siempre a otro rasgo universal del paraíso: su legendaria fertilidad, que se manifiesta en el crecimiento espontáneo, como por arte de magia, de una vegetación fabulosa (capaz de dar tres cosechas al año, según Hesíodo, Erga, 167-173). La explicación racionalista que vemos en Plutarco considera que, con la típica tendencia a la exageración propia del lenguaje mitológico, el mito se refiere a un hecho objetivo: la tierra de las Islas del Atlántico es "blanda y rica”, y gracias a la humedad del alisio y el clima templado las plantas pueden crecer más que en otros lugares. Cairasco va más allá, y por primera vez en la tradición clásica del paraíso relaciona esta feracidad mítica con una realidad natural totalmente novedosa para el hombre occidental:

Aquí florece la admirable selva

que el nombre ha de heredar del gran Doramas,

(...)

si aquí se corta un árbol, es notorio

multiplicar el tronco muchedumbre,

que arriba en pocos años al cimborio

de todos los demás, con igual cumbre.

(Sánchez, 1989: 178-179) 
Cairasco introduce la imagen del bosque tropical como espacio paradisíaco por excelencia, puesto que en él la fertilidad mágica del mito se verifica en el mundo real: en Canarias los árboles no solo no mueren al ser cortados (es decir, son inmortales, o cuando menos invulnerables), sino que además brotan de raíz en mayor número (un prodigio que parece calcado del mito de Hércules y la Hidra de Lerna), creciendo de nuevo hasta la bóveda arbórea con una milagrosa rapidez. Aunque suena otra vez a exageración o mitificación, lo cierto es que la descripción se basa en la observación empírica y es, del todo punto, real (la variedad de bosque que crece en las Islas, la laurisilva, posee esa facultad de brotar de raíz, constatada por los científicos).

Otro detalle imprescindible de la iconología del paraíso grecolatino consiste en su capacidad de suministrar abundantes alimentos para sus felices habitantes, sin necesidad de trabajar duro. Es algo que ya Plutarco había explicado en términos racionales, considerándolo simplemente una consecuencia de su fertilidad. Cairasco prosigue en esta misma línea, pero enriqueciéndola con algunas imágenes de cuño propio:

Mostróse pues el cielo en esta ínsula dándole amenos bosques, aguas frígidas que salen vivas de peñascos áridos y palmas por do va la yedra errática haciendo estrechos y amorosos círculos, que en muchas nacen regaladas támaras.

Las cañas dan finísimos azúcares, granados trigos las espigas cándidas, gustosísima miel las peñas cóncavas y vino singular los verdes pámpanos.

(Sánchez, 1989: 33-34)

En esta descripción, si bien encontramos ciertos dones de la Naturaleza, bien espontáneos (el agua o la miel) o cultivados (el trigo y el vino), que son convencionales, cabe destacar que otros son mucho más originales: los frutos de la palmera canaria (las támaras) y las cañas de azúcar añaden un toque de exotismo, y por 
vez primera introducen en la iconología del motivo tradicional del paraíso una novedad (plantas y sabores del trópico).

Más importante aún es que, junto con sus rasgos medioambientales, el paraíso se define por las características de sus moradores. En el mito disfrutan de un estilo de vida privilegiado, cuya causa principal es la liberación de la necesidad de trabajar. En la interpretación racionalista, este hecho recibe también su oportuna explicación: como bien dice Plutarco, se deduce que los productos de una Naturaleza tan espléndida "bastan para alimentar sin trabajo y afán a un pueblo ocioso". En su descripción de los habitantes de Canarias, Cairasco se atreve en sus imágenes a dar un paso más, para ensayar una explicación racional de otro rasgo fundamental de la existencia paradisíaca que se resiste a toda lógica:

Dioles un aire, un temple salutífero con que de gran tiempo se excusaron médicos y las mixturas del dorado fármaco,

(...)

Tan tarde entraba por las puertas Átropos, que pasaba la vida del centésimo, siendo los hombres sanos, fuertes, ágiles.

(Sánchez, 1989: 33)

Los bienaventurados que residen en el paraíso no solo están libres de trabajar, sino que escapan a las peores limitaciones de la condición humana: la enfermedad y la muerte. Para Cairasco, en las Islas no hay necesidad de médicos ni fármacos gracias a la salubridad del clima, y la misma muerte (encarnada aquí en Átropos) se ve obligada a ceder ante la proverbial longevidad de sus pobladores indígenas. En otro pasaje, el poeta retoma la imagen y la amplifica, dotando a los seres superiores que habitan el paraíso insular de nuevos dones físicos y mentales:

El cielo aquí con liberal franqueza
entendimientos dóciles reparte
y tal esfuerzo, fuerza y ligereza,
cual no se vio jamás en otra parte; 
y, lo que más admira, una extrañeza

de luenga vida, que parece en parte

que no conoce aquí la humana suerte

el general imperio de la muerte.

(Sánchez, 1989: 180)

En conclusión, gracias a una teoría filosófica acerca del mito, la literatura canaria del siglo XVI cumple uno de sus objetivos fundacionales: tomando como eje central el motivo mitológico y literario del paraíso, erige todo un imaginario propio. El principal índice de su éxito es que dicho imaginario ha conseguido asumirse internamente, reconocerse externamente y perdurar, durante más de cinco siglos, hasta hoy.

\section{Bibliografía}

Buffiere, F. (1973). Les mythes d'Homère et la pensée grecque. París: Les Belles Lettres.

García Gual, C. (2010). Introducción a la mitología griega. Madrid: Alianza Editorial.

Martínez, M. (1992). Canarias en la mitología. Sta. Cruz de Tenerife: Centro de la Cultura Popular Canaria.

Sánchez, A. (1989). B. Cairasco de Figueroa. Antología poética. Islas Canarias: Viceconsejería de Cultura y Deportes, Gobierno de Canarias. 